\title{
Floods in a Changing Climate
}

\author{
Theresa K. Andersen* and J. Marshall Shepherd \\ University of Georgia
}

\begin{abstract}
Atmospheric warming and associated hydrological changes have implications for regional flood intensity and frequency. Climate models and hydrological models have the ability to integrate various contributing factors and assess potential changes to hydrology at global to local scales through the century. This survey of floods in a changing climate reviews flood projections based on sources of precipitation, ice and snow melt, and coastal inundation. Topographic and anthropogenic influences that exacerbate or reduce flood risks by altering surface runoff, infiltration, storage, and precipitation development are also considered. Flood mitigation and adaptation strategies for infrastructure, agriculture, public health, and local communities are explored along with uncertainties and challenges in flood research. Recent and upcoming datasets to help with future flood monitoring and prediction include satellite missions, advanced radar, and in-situ networks.
\end{abstract}

\section{Introduction}

Floods are one of the world's leading natural disasters in terms of occurrence, economic losses, and victims (Guha-Sapir et al. 2012). Studies indicate loss of life and costs from flooding continue to increase (Ashley and Ashley 2008; Brissette et al. 2003; Shepherd et al. 2011), however, this observation may be driven by socio-economic factors (Barredo 2009; Bouwer 2011). As the hydrological cycle accelerates with current climate change, extreme events such as floods are likely to occur more frequently (Huntington 2006; Trenberth et al. 2007). Climate warming has recently been linked to intensification of heavy precipitation events over roughly two-thirds of the continental Northern Hemisphere (Min et al. 2011). The current body of literature indicates that the state of the climate and contributing factors to flood likelihood can be modeled with some certainty through the end of the century. The goal of this article is to (i) review the fundamentals of flood research, (ii) summarize regional flood intensity and frequency projections under climate change scenarios, (iii) understand contributing factors to flood events and (iv) highlight forthcoming datasets related to flood observation and forecasting.

\section{Fundamentals of Flood Research}

A flood can be defined as a "substantial rise in water that covers areas not usually submerged ... water flows into a region faster than it can be absorbed (i.e. soaked into the soil), stored (in a lake, river, or reservoir), or removed (in runoff or a waterway) into a drainage basin" (Ackerman and Knox 2012: 373). The flood warning system consists of monitoring, forecasting, and decision-making (Ghavasieh and Norouzi 2009). Recent advances in hydrological models, high-resolution regional climate models (RCMs), and downscaling techniques are helping researchers and decision-makers to better understand flood risks in the coming decades (Reynard et al. 2004). 
Hydrological models can be categorized as lumped conceptual models and distributed physically based models (Poelmans et al. 2010; Refsgaard 1997). Conceptual models represent either the full catchment or sub-catchment as a discretized unit and model rainfall-runoff conversion using simplistic parameterizations (Moore 2007). Distributed physically based models explicitly characterize land-hydroclimate processes in a catchment but are demanding in terms of input data and computational resources (Bhaduri et al. 2001). Distributed models often have more than twice as many variables as a conceptual model for the same area (Refsgaard 1997). Hybrid physico-conceptual models have also emerged (Ambrose 1999).

Downscaling can be used with general circulation models (GCMs) to produce data for fine scale hydrological applications and flood forecasting. Dynamic downscaling uses RCMs as a means to transform GCM data to finer-spatial scales but can be costly and time consuming (Chen et al. 2012). Alternatively, statistical downscaling uses algorithms such as multifractal cascades, non-linearly transformed autoregressive models, and cluster models with less computational time (Rebora et al. 2006).

Rainfall intensity-duration-frequency (IDF) curves consider statistics of historical rainfall events at a location for standard return periods and are often used for infrastructure design (i.e. "design storms") (Endreny and Imbeah 2009). The return period refers to the recurrence interval of a flood intensity. This metric is also a common source of confusion for many non-hydrologists as a 100-year flood is often assumed to occur every 100 years. However, it actually denotes a 1\% (1 chance in 100) probability of a flood of such magnitude happening in a year. Flood stage, discharge, and areal coverage are common measures of flood intensity (Figure 1). Flood control measures include pumps, dams and spillways, levees, trenches, weirs, and channelization (Kingsford 2000). Agencies such as the Army Corps of Engineers (US) and the Institution of Civil Engineers (UK) are tasked with strategic planning and managing flood risk (Wood et al. 2012). Large-scale engineering efforts to control flooding can transform a once meandering river into straighter channels with a simpler floodplain system. However, the channelization may disconnect the river from the floodplain, alter water quality, and reduce biodiversity (Kingsford 2000; Pegg et al. 2003). Despite control measures, floods cause reoccurring devastation in many regions of the world. Major sources of floods are intense or long-lasting precipitation, ice and snow melt, ice jams, storm surge, tsunamis, and dam or levee breaks. Pre-existing conditions such as saturated soil, soil crustal barriers, impervious artificial surfaces, and frozen ground can act to exacerbate flooding.
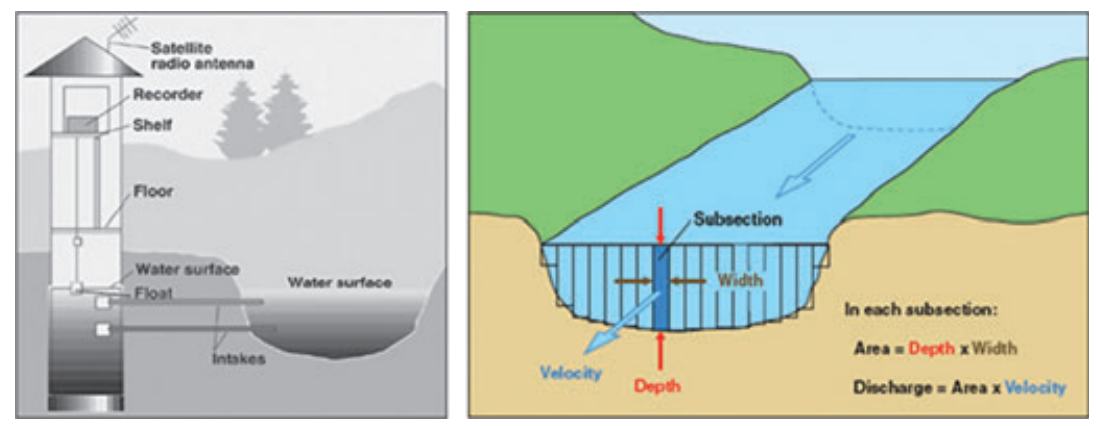

Fig. 1. Stage measurements along a river bank can be obtained with a streamgauge and stilling well (left). Total discharge, or rate of flow, is the sum of subsection discharges (right) (images courtesy of USGS). 
The fundamental Clausius-Clapeyron relationship states that the saturation vapor pressure increases as temperature increases. Observations confirm that both temperature and atmospheric water vapor quantity have been on the rise for decades (Trenberth et al. 2007). Warming trends may alter atmospheric and oceanic circulation patterns, jet streams, ice melt rate, and many other processes that ultimately have implications for extreme hydrological events. The following sections highlight research efforts related to regional and global flood projections in the coming decades.

\section{In a Warmer Climate}

\section{PRECIPITATION}

Increasing atmospheric moisture, or total precipitable water, due to warming temperatures has consequences for the intensity of rainfall events (Allan and Soden 2008; Pall et al. 2007). Observations indicate that extreme rainfall events have been increasing since the 20th century and long-lasting rainfall events are now "wetter" than normal (Brommer et al. 2007; Groisman et al. 2004). Precipitation intensity is expected to increase over much of the globe, particularly in the tropics, northern North America, south-central South America, northern Europe, northern and east coast Asia, and southwestern Australia (Meehl et al. 2005). In addition to sea level rise and tropical cyclones (TCs), precipitation is also contributing to increasing floods in coastal cities (Chang and Franczyk 2008). Simulations indicate that precipitation during the wettest intervals (i.e. flash floods) increases 30-100\% in many areas by the end of the century (Figure 2) (Dirmeyer 2011). As the atmosphere warms, more precipitation falls as rain rather than snow, which increases flooding risk in early spring (Trenberth 2011).

Precipitation intensity and distribution are also a function of atmospheric circulation changes. Models suggest that tropospheric warming tends to lower sea level pressure (SLP) in the mid-latitudes (Carnell and Senior 2002). Negative SLP anomalies across the northern hemisphere high latitudes produce more southwesterly flow, while negative SLP anomalies over southern hemisphere high latitudes produce more northwesterly flow helping transport moisture to the midlatitudes (Gillett and Stott 2009; Meehl et al. 2005). In the southern hemisphere, zonal wind variability is notably correlated to ascent of the tropopause (Lorenz and DeWeaver 2007). Observational data and climate models consistently

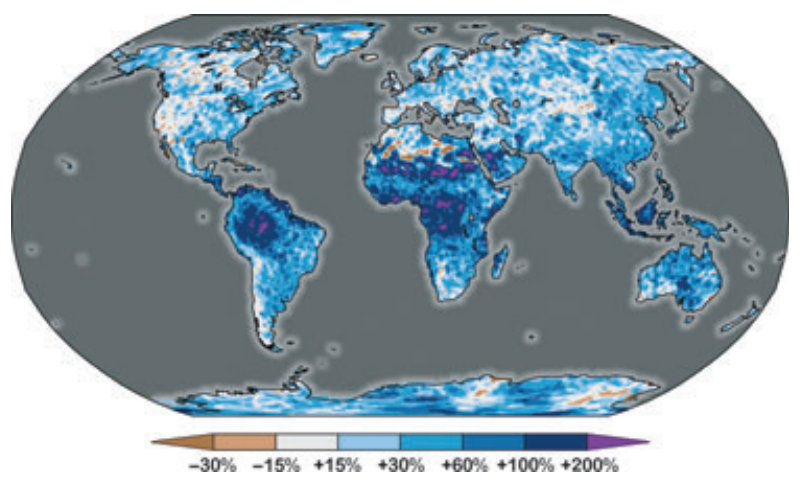

Fig. 2. Figure and caption following Dirmeyer (2011). "Change from the late 20th to the late 21st century in the average amount of precipitation occurring during the five wettest six-hour intervals (equivalent to the worst flash floods) in reference 47-year periods". 
indicate mid-latitude storm tracks and associated precipitation are shifting poleward along with synoptic-scale baroclinic waves and eddy-driven jet streams (Bender et al. 2012; Rivière 2011; Yin 2005). Storm tracks may also intensify in response to a greater energy imbalance (i.e. energy gain in tropics and energy loss in high latitudes) (Wu et al. 2011). The Sierra Nevada region, USA is expected to experience significantly greater magnitudes of flooding 2051-2099 due to increased storm size and frequency (Das et al. 2011). The low-level jet (LLJ) is an important control of summer precipitation distribution. Output from 18 GCMs under the A2 greenhouse gas emissions scenario suggests that by the end of the century the Great Plains LLJ will become stronger earlier in the year with a $20-40 \%$ increase in precipitation (Cook et al. 2008). Likewise, the South American Andes LLJ is predicted to strengthen and increase moisture transport to the south (Soares and Marengo 2009).

The south Asian monsoon, controlled by wind and temperature, is a major source of rainfall and flooding over India (Figure 3). Observations show that there is enhanced monsoon rainfall over South Peninsular India associated with a stronger easterly wind belt in recent decades (Naidu et al. 2012). Under warming scenarios, studies have found that an enhanced land-ocean temperature gradient (Hu et al. 2000) and increased moisture transport (Ueda et al. 2006) could strengthen the monsoon. Despite northward moisture transport, other findings suggest the monsoon will weaken (Sabade et al. 2011; Zheng et al. 2011). A possible explanation for this is the relatively minimal tropospheric heating over Asia compared to heating in other regions of the world (Zuo et al. 2012). Another study suggests that anomalous anticyclonic flow over the Arabian Sea and cyclonic flow over Tibet will weaken the easterly and westerly jet streams causing a weaker monsoon and both positive and negative rainfall anomalies (Sarthi et al. 2012). The east Asian monsoon is expected to respond to warming by changing position instead of intensity. A southward shift results in wetter conditions for the lower Yangtze River Valley and southern Japan (Li et al. 2010).

Large-scale climate indices and teleconnections drive persistent seasonal, annual, and decadal precipitation changes (Jain and Lall 2001; Kwon et al. 2011). El Ninõ-Southern Oscillation (ENSO) describes the coupled ocean-atmosphere variability in the tropical Pacific (Zhang et al. 2012). Currently, El Ninõ-related tropical rainfall has been increasing with wet regions becoming wetter at the expense of dry regions (Allan et al. 2010). However, future scenarios depict inconsistent precipitation patterns associated with positive and negative phases of ENSO (Zhang et al. 2012). The North Atlantic Oscillation

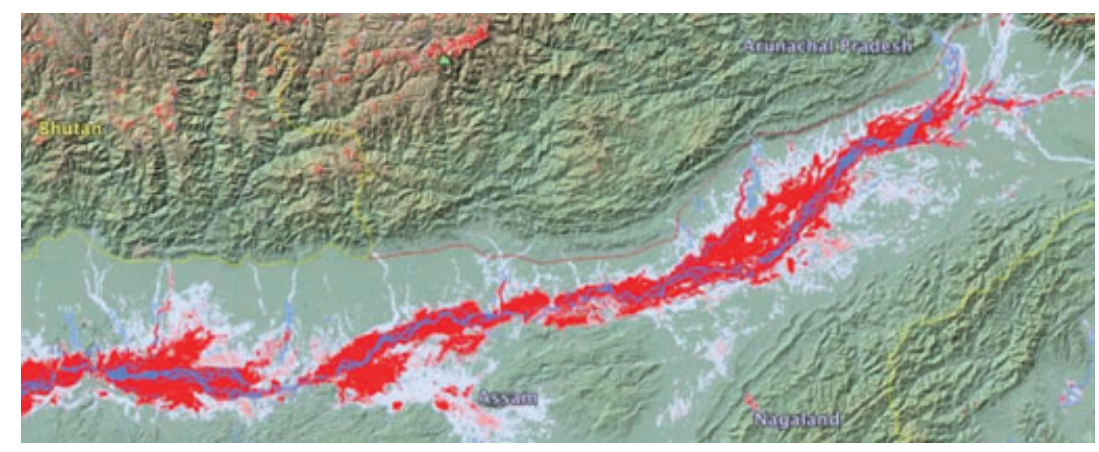

Fig. 3. Flooding (red areas) in Assam, India during the summer of 2012 (image courtesy of Dartmouth Flood Observatory). 
(NAO) redistributes atmospheric mass between the Arctic and subtropical Atlantic (Hurrell and Deser 2009). It is projected that the winter NAO positive phase will strengthen over the next century with less frequent precipitation for the mountainous Mediterranean and Morocco (López-Moreno et al. 2011; Tramblay et al. 2012). There is not an evident trend in future NAO phases or corresponding winter precipitation in the mid-Atlantic (Ning et al. 2012). The Pacific Decadal Oscillation (PDO) and North Pacific Gyre Oscillation (NPGO) are prevailing modes of North Pacific ocean variability. The future temporal and spatial changes in these oscillations are vague, but melting Arctic sea ice is likely to have an impact (D'Orgeville and Peltier 2009; Furtado et al. 2011). The Madden-Julian Oscillation (MJO), an index of intraseasonal tropical variability, is known to influence monsoons, extreme precipitation, and ENSO. A stochastic modeling study projects the mean number of annual MJO events could increase from 3.9 (1948-2008) to 5.7 (2049-2099) (Jones and Carvalho 2011).

Trends of precipitation frequency and intensity have significant implications for surface hydrology and future flooding. By mid-century, projections compute increases in global mean precipitation rate (5.2\%), global runoff $(7.3 \%)$, eastern equatorial Africa runoff (1040\%), La Plata basin runoff (10-40\%), and high-latitude North America runoff (10-40\%). Runoff decreases of 10-30\% are expected in southern Africa, southern Europe, the Middle East, and western North America (Milly et al. 2005; Wetherald and Manabe 2002). By the end of the century, runoff may increase by $16 \%$ globally and $27 \%$ at northern latitudes (1800-2100) (Nugent and Matthews 2012). Regionalized climate scenarios predict an increase in peak flows associated with 5, 25, 50, and 100-year return periods from the 2020s to 2080s (Bastola et al. 2011). Generally, a 100-year flood may occur twice as often in the future (Schiermeier 2011). Areas of the world known for deadly flood events will continue to be susceptible. In Bangladesh, hydrological models indicate substantial increases in mean peak discharges in the Ganges, Brahmaputra, and Meghna rivers (Mirza 2002). Near the Yellow River, China, total annual runoff could decrease, but inconsistent runoff distribution may lead to severe floods (Li et al. 2008). The maximum hourly discharge is expected to increase in north-central and southwestern tributaries of the Chao Phraya basin, Thailand, while flood risk decreases at the Pasak river (Hunukumbura and Tachikawa 2012).

\section{ICE AND SNOW MELT}

Ice and snowpack from mountains and upstream of rivers can reduce or amplify flood potential. Research suggests warming generally leads to earlier snowmelt and diminished snowpack, however, mid-winter snowfall could increase in continental regions (Trenberth 2011). In a study of the Columbia River in the Pacific Northwest, future warming causes reduced winter snowpack and reduced peak streamflows earlier in the spring (Lee et al. 2009). The San Francisco estuary and upstream watershed in California, USA is projected to lose about half of its historical April snowpack with a $20 \%$ reduction in annual runoff and increase in winter flood peaks by 2090 (Knowles and Cayan 2002). In the Alpine region, climate change simulations predict permanent snow cover at altitudes above $3000 \mathrm{~m}$ would vanish, comparable to shifting the elevation zones down by $900 \mathrm{~m}$. Peaks in snowmelt discharge could become confined to spring, while more rain than snow events in the fall increase the likelihood of flooding (Bavay et al. 2009).

Glacial outburst floods, or jökulhlaups, originate from water reservoirs at the surface, base, front, or margins of a glacier. Moraine dam failure, ice dam failure, or overlying pressure drains water causing flash floods (Huggel et al. 2002). Future flood probability 
depends on lake volume, geometry and structure of the dam, and triggering mechanisms (Benn et al. 2012). Overdeepened sections of glacier beds from glacier retreat have been identified using digital elevation models and detailed measurements in an attempt to locate future glacier lake locations due to accelerated melting (Frey et al. 2010). Aerial photographs and field research show that Himalayan glaciers are thinning while subglacial lakes are expanding producing an impending risk of outburst floods for Nepal and surrounding areas. Deglaciation will also impact river characteristics and freshwater resources (Shrestha and Aryal 2011). Debris-covered glaciers near Mount Everest have been losing mass, breaking up drainage networks and forming supraglacial lakes in hollows (Benn et al. 2012). A rapidly growing base-level lake on Ngozumpa Glacier west of Mount Everest could potentially burst in the next 2-3 decades (Benn et al. 2012). Himalayan glaciers are particularly sensitive to global warming as the snowpack is formed during the summer monsoon season (Shiho and Osafumi 2008). Accelerated glacial melt has also influenced the frequency or magnitude of outburst floods in the Karakoram mountains along the Yarkant river, China, the Caucasus range, Russia, and Cordillera Blanca, Peru (Chen et al. 2010; Hegglin and Huggel 2008; Petrakov et al. 2012).

Ice jams are a common phenomenon in the mid-high latitudes during springtime thaw. As frozen layers of a river begin to melt, chunks of ice accumulate and force the water to backup. Arctic deltas are particularly vulnerable to changes in ice breakup. In the Mackenzie Delta, Canada, there is a trend for earlier occurrence and more variable severity of ice jams (Goulding et al. 2009). Along the Saint-Francois River, Canada, increases in winter temperatures are causing ice jams earlier in the year with a higher incidence of flooding (Ouellet et al. 2012). A case study of the Peace River in Canada utilized a thermo-hydraulic river ice model to simulate the effects of climate change on river ice cover. Results indicated that ice duration may be reduced $41-63 \%$ under the A2 scenario with delayed bridging (i.e. peak ice congestion) (Andrishak and Hicks 2008). However, ice breakup regimes vary locally. Midwinter thaws are expected to increase in frequency and in some instances will reduce both snowpack and subsequent ice jam flooding (Beltaos 2007). Although flooding is often associated with negative impacts, in the arctic region ice jam flooding is essential to maintaining the health of the river ecosystem. Channel flow control strategies via dams have been implemented to induce ice jam floods and replenish delta ponds in cases where climate change has reduced natural ice jam events (Figure 4).

\section{COASTAL FLOODING}

Sea-level rise, tides, tsunamis, and TCs pose additional flood risks for cities along the coast (Huong and Pathirana 2011; Usmani and Vachani 2011). Median sea level is expected to rise $0.57-1.10 \mathrm{~m}$ by 2100 and continuing rising up to $5.49 \mathrm{~m}$ by 2500 (Jevrejeva et al. 2012). Can Tho, Vietnam is a city facing these coastal challenges in addition to urban growth-induced runoff and microclimate changes. Simulations of climate change and urban growth for the city indicate flood inundation depth could increase up to $80 \%$ by 2050 (Huong and Pathirana 2011). In a similar situation, future recurrence intervals for the northeast US reveal that the elevation of the 2005 100-year flood could be equaled or exceeded every 30-70 years as sea level rises (Kirshen et al. 2008). In Ghana, receding coastlines and episodic tide floods could expose $0.80 \mathrm{~km}^{2}$ of land to permanent inundation by 2100 (Addo et al. 2011). Rural areas, such as the coastal villages in West Bengal, India, may be more vulnerable to flooding due to lack of planning and aid (Bhattacharya and Guleria 2012). Although tsunami development is not directly related to 

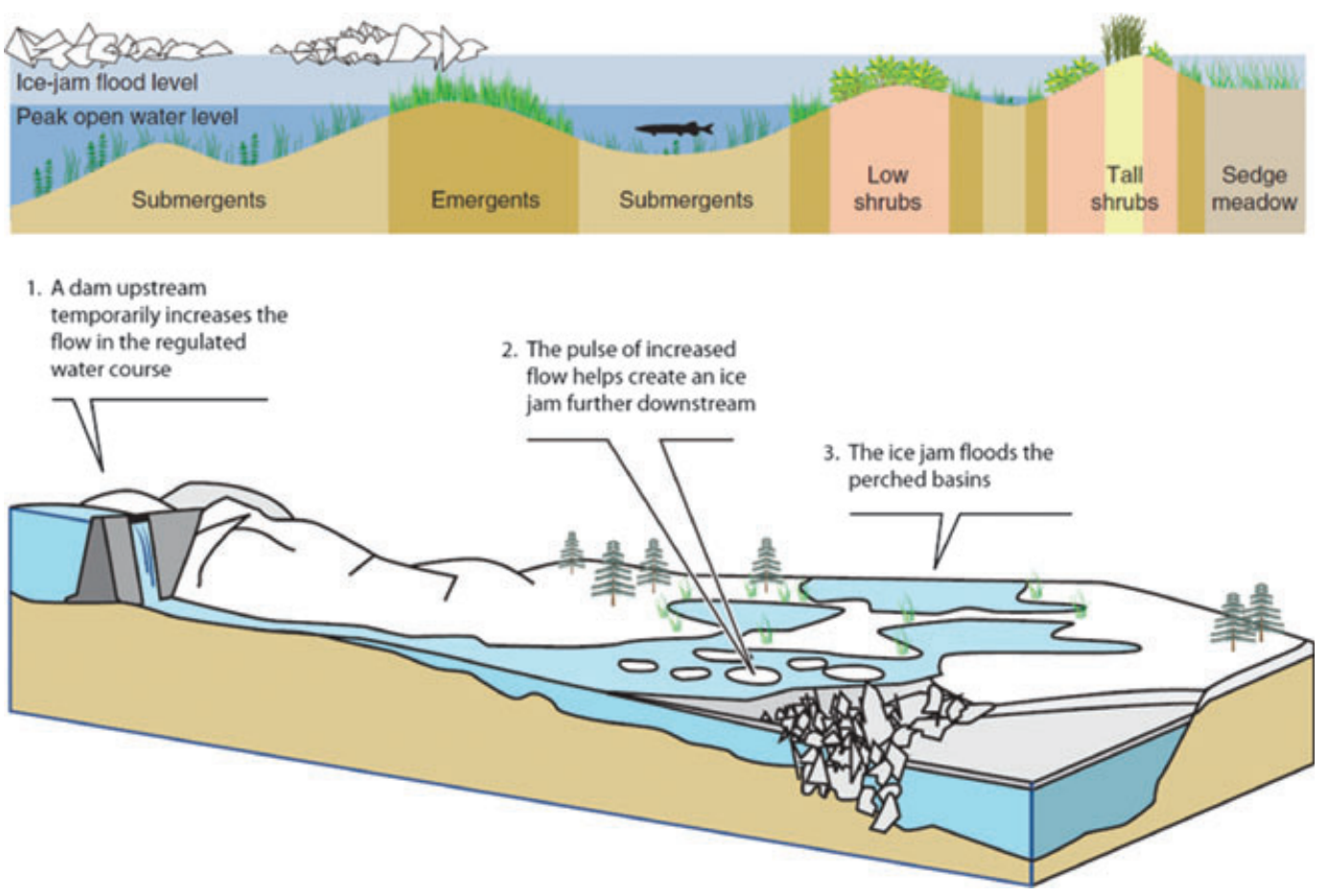

Fig. 4. Ice jam flooding is essential to ecosystem health in Arctic rivers but is becoming infrequent due to reduced snowpack and ice thinning. Flow control measures have been implemented as a strategy to induce ice jams and maintain delta ponds (image courtesy Hugo Ahlenius, UNEP/GRID-Arendal at http://www.grida.no/graphicslib/ detail/arctic-delta-pond-ecosystems-seasonal-flooding-and-adaptation_b05f\#).

a warming climate, rising sea levels could amplify tsunami flooding along coasts (Usmani and Vachani 2011).

Severity of flooding from TCs is related to storm motion and intensity, tides, bathymetry along shore, and sea level (Figure 5). Studies have suggested that intense (i.e. CAT 4/5) and long-lived TCs increase in frequency as sea-surface temperature warms (Bender et al. 2010; Hill and Lackmann 2011; Murakami et al. 2012). Recent high-resolution GCMs show reduced frequency of TCs 2075-2099 with consistent decreases in the western North Pacific, South Indian, and South Pacific oceans and inconsistent trends in the North Atlantic and eastern North Pacific oceans (Murakami et al. 2012). In Florida, USA, future climate scenarios predict TC trends will have minimal influence on coastal inundation considering reduced TC frequency somewhat negates increased TC intensity (Condon and Sheng 2012). However, there remains large uncertainty in future TC intensity, frequency, distribution, and tracks (Emanuel et al. 2008; Kim et al. 2011; Shepherd and Knutson 2007). Limited records, data inhomogeneities, environmental factors, and various climate processes complicate trends (Hill and Lackmann 2011; Shepherd and Knutson 2007).

\section{Contributing Factors}

TOPOGRAPHY AND SOIL CONDITIONS

Landslide debris that moves into stream and river channels can form dams on various time scales. The sudden release of water behind the blockage often unleashes unpredictable 


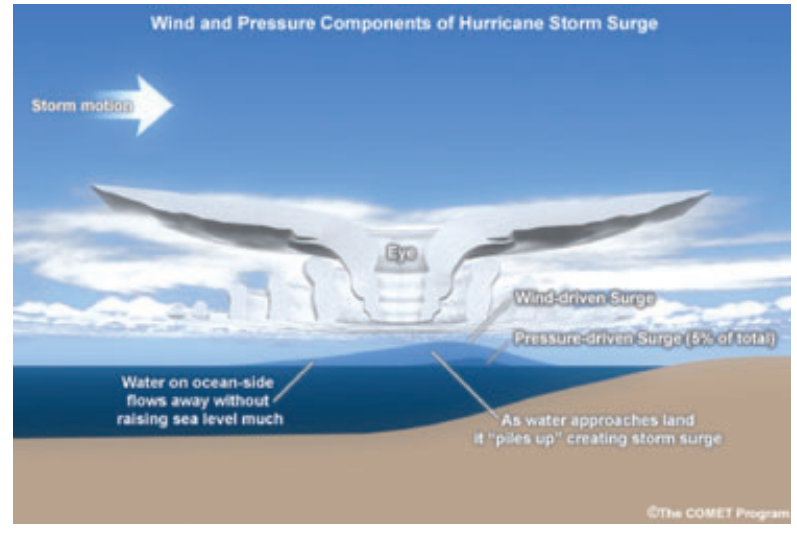

Fig. 5. Schematic of tropical cyclone storm surge. The storm motion and intensity, tides, bathymetry along shore, and sea level determine the severity of storm surge flooding (image courtesy of The COMET Program).

flash floods (Catane et al. 2012). Earthquakes trigger landslides in regions such as Japan and Taiwan. Seismic networks, physically based models, statistical analysis, and geographic information systems are used to determine landslide susceptibility and hazards (Wasowski et al. 2011). Human activities, rainfall, and other natural processes also contribute to landslides on unstable slopes (Van Den Eeckhaut et al. 2009). Hazard maps and probability of occurrence approaches are used for assessing future landslides, however, insufficient data can make it difficult or impossible to assess for certain situations (Chung 2006; Lopez Saez et al. 2012). In mountainous regions around the world, degrading permafrost and ice melt may destabilize slopes and lead to larger debris flows (Stoffel and Huggel 2012). Along the southern coast of British Columbia, landslides are expected to become more frequent as antecedent and short-term precipitation increase (Jakob and Lambert 2009). In the western North Pacific, intensifying rainfall rates and typhoons are predicted to increase landslide activity. A landslide prediction model suggests total unstable area in Taiwan could increase 12\% this century (Chiang and Chang 2011).

Wet soil and wet-dry soil boundaries can feedback to the atmosphere to generate convection and precipitation. This land-atmosphere feedback may be enhanced in a warmer climate due to greater latent heat flux (Dirmeyer et al. 2012). Soil moisture conditions also influence the degree of infiltration during a rainfall event. Saturated soils, very dry topsoils, and frozen ground promote overland flow and flooding potential. RCMs predict greater regional differences in soil moisture values by 2030 in which dry regions become drier and vice versa. Northern Europe, eastern US, northwestern South America, and southern Asia may experience alleviated annual soil moisture deficits and increased surface runoff (Tao et al. 2003). Varying soil moisture distributions were recently discussed in a special report of the Intergovernmental Panel on Climate Change (IPCC 2012) (Figure 6). In a study of diurnal soil moisture changes under warming scenarios in northern China, mean volumetric soil moisture $(0-40 \mathrm{~cm})$ decreased more significantly during day warming compared to night warming (Xia et al. 2010).

\section{HUMAN IMPACTS}

Anthropogenic roles in contributing to flood events have been a recent topic of interest as researchers are challenged with isolating human impacts from other factors. Conversion 


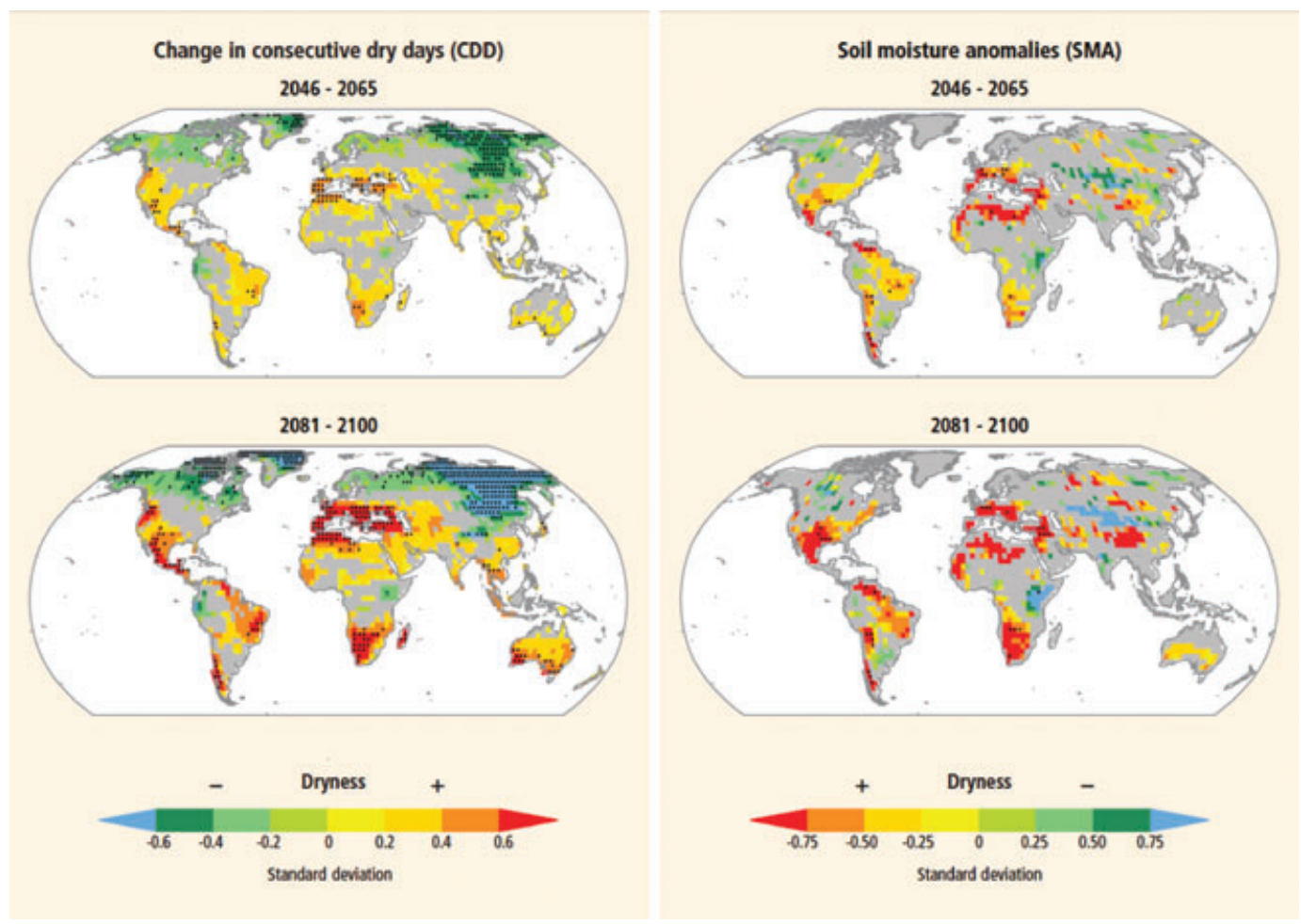

Fig. 6. Projected annual changes in dryness assessed from change in annual maximum number of consecutive dry days (precipitation $<1 \mathrm{~mm}$ ) (left) and changes in soil moisture (soil moisture anomalies) (right) relative to 19801999. Colored shading indicates at least $66 \%$ of the GCM simulations agree on the sign of the change (image courtesy of IPCC 2012).

of agricultural lands to industrial areas and reservoir operation policies are suggested to have set the stage for the 2011 Thailand floods (Van Oldenborgh et al. 2012). Rivers in central and southern Thailand topped banks and submerged nearby cities causing an estimated $\$ 45$ billion in damage (Figure 7). Using a probabilistic event framework, the Whales, UK flooding in 2000 during the wettest autumn on record has been attributed to a $20-90 \%$ increase in risk occurrence due to anthropogenic warming (Pall et al. 2011). Subsidence in New Orleans, partly caused by wetland drainage and soil compaction, weakened levees prior to Hurricane Katrina (Dixon et al. 2006).

Urban land use accelerates hydrologic response through surface runoff variability and stresses on conveyance systems amplifying urban flooding risks (Reynolds et al. 2008; Shepherd et al. 2011; Villarini et al. 2010a). Furthermore, such processes reveal weaknesses in urban hazard response, water management systems, and drainage (NAS 2012). Over the next few decades, urban land cover is expected to increase from $4 \%$ to $8 \%$ in the US (Nowak and Walton 2005) and nearly all of the world's population growth is anticipated to occur in urban areas in developing countries, regions particularly vulnerable to flooding (Cohen 2006). Urban areas have also been shown to modify the temporal and spatial distribution of precipitation above and downwind of the city (Shem and Shepherd 2009). Urban heat, irrigation practices, surface roughness, and aerosol release can promote cloud and precipitation development (Ashley et al. 2012). The Metropolitan Meteorological Experiment, satellite observations, and urban-rainfall modeling have demonstrated that urban effects lead 

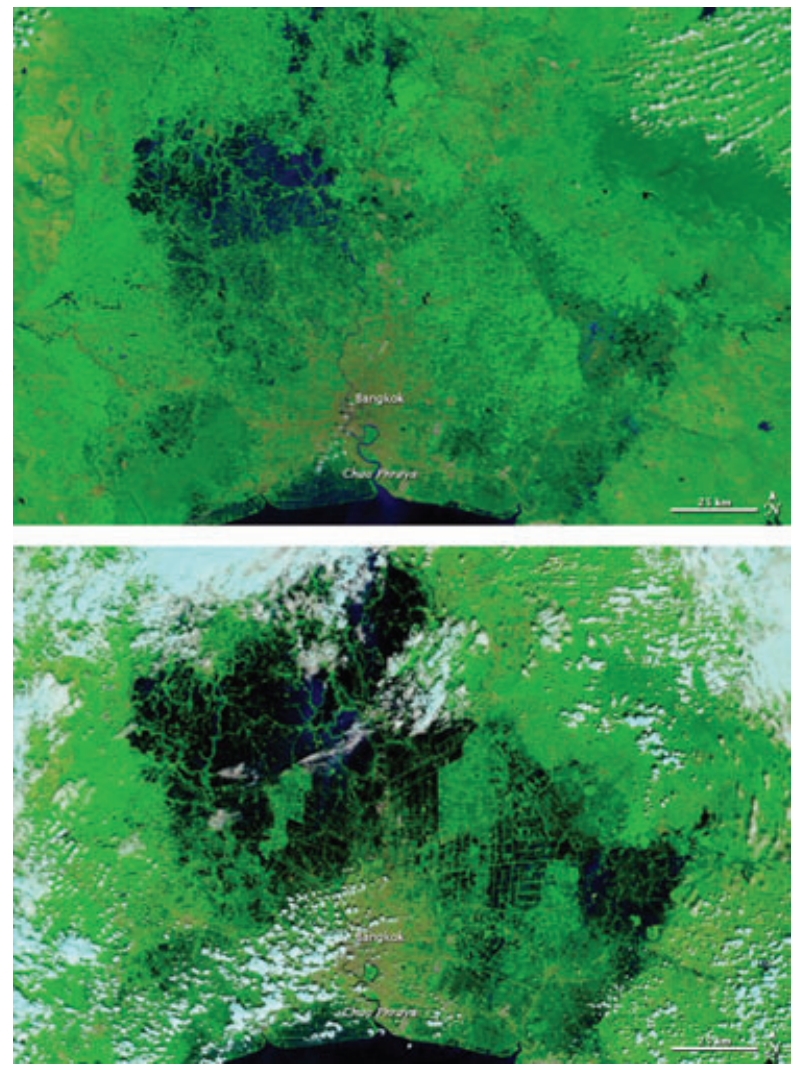

Fig. 7. The Moderate Resolution Imaging Spectroradiometer (MODIS) on NASA's Terra satellite captured images of Thailand and Cambodia on November 13, 2008 (top) and after flooding on October 25, 2011.

to enhanced precipitation during warm months (Shepherd 2005). The 2009 flooding in Atlanta, Georgia, USA may have been related to urban meteorological and hydrological interactions (Shepherd et al. 2011). In Japan, rainfall intensity has been observed to increase over urban areas due to excess heating (Aikawa et al. 2009).

Additional land use and land cover changes alter surface hydrology. Loss of forest cover reduces frictional effects, increases water flow rate, and amplifies flood-related disasters (Wissmar et al. 2004; Bradshaw et al. 2007). A comparison between a forest in the Amazon and an adjacent deforested pasture reveals a doubling of overland flow frequency and 17-fold stormflow volume increase in the pasture (Germer et al. 2010). In Alberta, Canada, land use change projections show increases in built up land, ranges and parks, and agricultural land while deciduous and evergreen forest decrease. Due to changing land cover in the area, hydrological models predict a $7.3 \%$ increase in overland flow and $2.3 \%$ decrease in infiltration 2001-2031 (Wijesekara et al. 2012). Similar hydrological effects of land cover change have recently been noted in northeastern Iran and Santiago de Chile (Müller and Reinstorf 2011; Panahi et al. 2010).

\section{Adaptation, Mitigation, and Future Risks}

Human populations have historically clustered near coastal areas and freshwater resources, areas prone to flooding disasters. Global annual losses due to weather-related disasters 
have reached over $\$ 200$ billion, with flooding as a leading cause (IPCC 2012). Although developing countries often have the greatest losses from flood events, wealthy countries are also vulnerable. For example, the 1993 severe flood along the Mississippi River Basin, USA, resulted in $\$ 12-16$ billion in fiscal damage with over 500 counties declared disaster areas (Ashley and Ashley 2008; Pitlick 1997). In South Holland, sea-level rise and extreme river discharges may quadruple the number of flood-related fatalities by 2040 (Maaskant et al. 2009). Nearly $20 \%$ of the global population living in river basins may be impacted by increased probability of large-scale floods (Kleinen and Petschel-Held 2007).

Risk-based design of hydraulic structures is an integral part of mitigation planning to reduce flood damage (Heidari 2009). Current flood standards and policies are being reexamined to account for possible hydrological changes (Danso-Amoako et al. 2012; England 2011; Gersonius et al. 2012; Griffiths et al. 2009). Coupled with the influence of urban hydrological response, assessment of urban flood potential may be biased by stationarity assumptions and outdated curve methods (NAS 2012). Updating of flood intensity and frequency methodologies must evolve to reflect possible climate changeurbanization-extreme events associations. Research reports that in the Netherlands, the impacts of water management on river floods are greater than the impacts of climate change (Tol et al. 2003). In Denmark, updated guidelines for urban drainage design and IDF curves have been proposed as storm intensities increase (Madsen et al. 2009). Rainfall-runoff simulations of the Soyang Dam watershed, South Korea indicate design flood can be increased 10\% under a warming scenario (Kwon et al. 2011). In the UK, 5000 dams are reported at risk of failure due to embankment subsidence, erosion, and severe rainfall events (Danso-Amoako et al. 2012). Western Europe flood damages are expected to rise with hundreds of thousands more people affected by flooding by the end of the century (Feyen et al. 2012). By 2030, flood damages along the River Rhine may increase 54-230\% with the highest risk in Germany (te Linde et al. 2011). Flood damage caused by design storms at Kanda River basin, Japan, under climate change scenarios may double the estimated risk cost in the 21st century (Morita 2011). Alternative to infrastructure design, land cover mitigation strategies such as reforestation have also been shown to reduce flooding effects in China (Qiu et al. 2010) and the United States (Ayer 2007).

In response to sea level rise in Australia, policy goals have proposed coastal community protection, accommodation, and managed retreat (Alexander et al. 2012). However, the fairness of government-sponsored resettlement as an adaptation option is disputed (Wilby and Keenan 2012). In Bangladesh, a flood-proofing program has taken action by raising homes onto earth platforms (Wilby and Keenan 2012). Insurance policies are an option for some communities living in flood-prone areas, however, the availability and affordability of policies is at risk (Mills 2005). In the Netherlands, prospects of long-term flood insurance contracts are becoming undesirable in the face of climate change. A publicprivate insurance scheme is proposed as a more robust approach than private insurance (Aerts and Botzen 2011). An assessment on the susceptibility of the US National Flood Insurance Program to climate change impacts was recently commissioned. Research found that changing storm characteristics and sea level rise could expand flood hazard areas (Divoky et al. 2012). It has been suggested that flood insurance be utilized with caution. Responses to increase adaptive capacity, such as subsidized insurance, can be offset by actions that increase exposure (Mcleman and Smit 2006).

Local agriculture and food production could be impacted by future flood events. Global food security will rely on adaptation and mitigation to climate change as optimal crop conditions shift (Adeloye 2010). In Ghana, model mapping tools are helping stakeholders plan for food security and sustainability as increasing flood events threaten farmland 
(Dwamena et al. 2011). Likewise, integrated farming systems and watershed management are needed to help maintain crop yields in vulnerable areas of India (Faroda and Poonia 2012). In regions with less developed environmental policies, "living with floods" may be a viable option. In countries such as Mexico and Mozambique, agricultural land can serve as temporary wetlands during flooding. Floods could seasonally replenish farmland soil moisture and nutrients and also deter residential development (Eakin and Appendini 2008).

Climate change could potentially amplify existing public health hazards or introduce new threats in both developing and industrial nations (Hess et al. 2012). Public health issues stemming from increasing flood events include water contamination and disease outbreaks. The global distribution and risks of water-borne diseases, such as Cholera, could be altered (Charron et al. 2004). In Canada, excess precipitation, flooding, and erosion could lead to surface and ground water contamination (Charron et al. 2004). Increasing runoff in the Netherlands is expected to escalate waterborne pathogens and infection risk (Schijven and Husman 2005). According to Hess et al. (2012), "Developing a centralized tool repository should be a high priority and, along with increased focus on learning, modeling, and adaptive management, will help increase the resilience of local public health systems".

\section{Uncertainty}

Current research provides insight into future trends in regional flooding, changes in various contributing factors, and related risks. Although there are continual advances and improvements in modeling capabilities, there are still sources of uncertainty and challenges. Research has shown that the largest source of flood frequency uncertainty is from GCM structure when compared to greenhouse gases, downscaling, hydrologic model structure and parameters, and the internal variability of the climate system (Kay et al. 2009). Furthermore, multiple GCMs provide more reliable output compared to any single GCM in hydrological downscaling studies (Chen et al. 2012). Research on future flood damage found that absolute damage estimates vary by a factor of 3.5-3.8, while relative damage estimates vary by a factor of 1.4 when applying different modeling approaches. Modeling can be improved by integrating multiple damage-related parameters (Bubeck et al. 2011). Challenges in flood research include integrating multiple scales of data, feedbacks between climatic and hydrologic systems, coupling climate and land-use models, and linking flood damage to socioeconomic data (Chang and Franczyk 2008).

Uncertainties in hydrological models include (i) errors and limitations in input datasets, (ii) parameterization or assumptions in the model, (iii) calibration errors, (iv) land classification/cover errors, and (v) catchment scale/transfer errors (Coon and Reddy 2008). It has also been noted that when dealing with precipitation and hydrology, a deterministic forecast gives the user an "illusion of certainty" whereas a probabilistic system inherently accounts for uncertainty. An American Meteorological Society (AMS) policy statement on flooding acknowledges the opportunities and challenges of providing probabilistic forecast guidance (Villarini et al. 2010b).

\section{Future Datasets}

Remote sensing plays an important role in observing hydrologic conditions. Several satellite missions are scheduled to launch in the next few years that will be useful for flood prediction and monitoring. Landsat Data Continuity Mission (2012 launch) with a 
Thermal Infrared Sensor (TIRS) will measure evapotranspiration rate and monitor floods (Irons et al. 2012). Geostationary Operational Environmental Satellite - R Series (2015 launch) will carry an Advanced Baseline Imager (ABI) to measure rainfall rate, rainfall potential, and probability of rainfall (Goodman et al. 2012). Global Precipitation Measurement (GPM) mission (2014 launch) with an advanced radar and radiometer will measure light to heavy rainfall and snowfall in three-dimensions (Tapiador et al. 2012). Soil Moisture Active Passive (SMAP) mission (2014 launch) includes a synthetic aperture L-band radar and radiometer for measuring soil moisture and soil freeze/thaw state (Entekhabi et al. 2010). Cutting edge technology has proved useful for quality precipitation measurements. The US National Severe Storms Lab has demonstrated the operational capabilities of dual polarimetric radar, which transmits radio pulses in both horizontal and vertical directions to obtain improved precipitation rates and detection (Ryzhkov et al. 2005). Hydro-NEXRAD (Next-Generation Radar) is a recently created software system that can generate customized rainfall maps from high resolution Doppler radar reflectivity data for a variety of hydrological applications (Krajewski et al. 2011). Global Positioning System (GPS) receivers have been proposed as a tool to create a global soil moisture database in near real-time. GPS L-band signals can be used to estimate soil moisture variations and would complement future satellite datasets (Larson et al. 2008)

In situ soil moisture networks are useful for improving satellite observations and hydrologic models, and observing trends. The volunteer-based International Soil Moisture Network provides standardized soil moisture data globally and is quickly expanding to include more stations and networks (Dorigo et al. 2011). Networked small-scale weather stations are useful for obtaining local hydrological information. The Community Collaborative Rain, Hail, and Snow network (CoCoRaHS) invites volunteers to record precipitation measurements using low-cost rain gauges and hail pads. Data is publicly available online for use by amateurs and professionals alike (Reges et al. 2010). The National Weather Service (NWS) cooperative observer program also uses volunteers to compile long-term climate changes and real-time meteorological data. The data are vital to monitoring floods and environmental planning, however, there are issues with quality control and spatial resolution (Westcott et al. 2008).

\section{Summary}

The current warming of the atmosphere is associated with an accelerating water cycle and increasing extreme hydrological events. This survey aims to understand possible flood trends, damage, and risk under climate change scenarios. The current body of climate change research commonly provides insight into future floods through GCMs, RCMs, and hydrological model studies. Runoff sources are assessed through research on precipitation, ice and snow melt, sea level, and storm surge. Topography, soil conditions, and human influence are identified as aspects that could amplify or reduce flood impacts. Approaches to mitigating and adapting to flood risks, uncertainties in research, and upcoming datasets are also explored. The key projections related to flooding under a warmer atmosphere are as follows:

1 Atmospheric warming generally increases evaporation and water vapor quantity. Extreme precipitation events are becoming more intense and frequent, and more precipitation will fall as rain rather than snow.

2 Atmospheric circulation patterns are changing. Mid-latitude storm tracks and associated precipitation are shifting poleward and LLJs are strengthening and producing 
more precipitation in the Great Plains and South American Andes. The East Asian monsoon may shift southward while changes in the South Asian monsoon are disputed. There are no clear trends for large-scale climate indices and teleconnections with the exception of more frequent MJOs.

3 Global mean precipitation rate and runoff are increasing, particularly in northern latitudes, with variable local and regional trends.

4 Warming causes earlier snowmelt and diminished snowpack, however, mid-winter snowfall could increase in continental regions. Mountain glaciers are thinning and subglacial lakes are expanding producing a greater risk of outburst floods near the Himalayas, Karakoram mountains, the Caucasus range, and Cordillera Blanca. River ice jam events are occurring earlier in the year. Ice breakup regimes vary locally and could either lead to increased or decreased flooding.

5 Sea level rise, tides, and receding coastlines are increasing inundation in coastal cities. Intense TCs are becoming more frequent, while TCs overall are becoming less frequent. However, uncertainties coupled with various climate processes complicate flooding consequences.

6 Intensifying rainfall rates and land use on unstable slopes will increase landslide activity. Potential for flash floods could increase as more debris dams form. Regional soil moisture anomalies are increasing with implications for degree of infiltration, runoff, and enhanced atmospheric feedbacks.

7 Deforestation and urban growth promote increased precipitation runoff and exacerbate flooding. In some cases, urban areas also modify convective development and precipitation above and downwind of the city. Nearly all of the world's population growth is anticipated to occur in urban areas in developing countries.

8 Flood events are impacting more people globally and are expected to lead to more damage and fatalities. Infrastructure, design storms, and IDF curves need to be updated to account for non-stationary of storm intensity. The most vulnerable communities are rural or developing areas that lack planning and resources.

9 Agricultural output and practices may be impacted by shifts in weather patterns and changing hydrological conditions. Global food security relies on efforts to engage stakeholders in planning and policy.

10 Increased runoff and flooding may alter the global risk of water contamination and distribution of water-borne diseases. The resilience of public health systems relies on education, modeling, and adaptive management.

11 The largest source of uncertainty in hydrological studies stems from the GCM. Use of multiple GCMs can help to reduce biases and errors.

Future datasets that help in the monitoring and prediction of floods include satellite missions (e.g. Landsat Data Continuity Mission, Global Precipitation Mission), radar (e.g. dual polarimetric, NEXRAD), and in situ (e.g. International Soil Moisture Network, National Weather Service cooperative observer program). Contradicting and unclear outcomes will continue to be addressed by researchers to provide the most objective information for decision-makers and the public.

\section{Short Biographies}

Theresa Andersen is a doctoral candidate at the University of Georgia (UGA) and holds a NASA Earth and Space Science Fellowship. She has been a member of the American Meteorological Society (AMS) since 2004 and has presented research at several 
conferences. Ms. Andersen taught an introduction to weather and climate laboratory for 3 years and contributed to a journal article on active learning in the classroom. More recently she has provided academic tutoring to UGA undergraduates taking geography courses. She is currently researching soil moisture-atmospheric feedbacks with implications for cyclones. In an online article, she explored this feedback in relation to historical tornado days, while a forthcoming publication focuses on landfalling hurricanes. She holds a BS degree in meteorology from Iowa State University and MS degree in geography from UGA.

Dr. J. Marshall Shepherd is a full professor of geography/atmospheric sciences at UGA and Director of the UGA Atmospheric Sciences Program. He is the 2nd African American to serve as President-Elect of the AMS and will become president in January 2013. Prior to joining the UGA faculty, Dr. Shepherd spent 12 years as a research meteorologist at NASA. Dr. Shepherd was honored in 2004 at the White House with the Presidential Early Career Award (PECASE) for pioneering scientific research. Dr. Shepherd is a Fellow of the AMS, has over 60 scientific publications. He is a member of several boards, including the NOAA Science Advisory Board and NASA Earth Science Advisory Committee. He was a contributing author on the 2007 Inter-governmental Panel on Climate Change (IPCC) AR4 report amongst other activities. Dr. Shepherd is also the author of the forthcoming textbook, The Urban Climate System, and the collaborating author on the children's book, Dr. Fred's Weather Watch. Dr. Shepherd received his BS, MS and $\mathrm{PhD}$ in physical meteorology from Florida State University.

\section{Note}

* Correspondence address: Theresa K. Andersen, Department of Geography, University of Georgia, Room 31A, Athens, GA 30602, USA. E-mail: tkande@uga.edu.

\section{References}

Ackerman, S. A. and Knox, J. A. (eds.) (2012). Meteorology: understanding the atmosphere. Sudbury: Jones \& Bartlett Learning, LLC.

Addo, K. A., Larbi, L., Amisigo, B. and Ofori-Danson, P. K. (2011). Impacts of coastal inundation due to climate change in a cluster of urban coastal communities in Ghana, West Africa. Remote Sensing 3, pp. 2029-2050. doi: $10.3390 / \mathrm{rs} 3092029$.

Adeloye, A. A. (2010). Global warming impact: flood events, wet-dry conditions and changing scene in world food security. Journal of Agricultural Research and Development 9 (1), pp. 1-15.

Aerts, J. C. J. H. and Botzen, W. J. W. (2011). Climate change impacts on pricing long-term flood insurance: a comprehensive study for the Netherlands. Global Environmental Change 21 (3), pp. 1045-1060. doi:10.1016/j. gloenvcha.2011.04.005.

Aikawa, M., Hiraki, T. and Eiho, J. (2009). Change of atmospheric condition in an urbanized area of Japan from the viewpoint of rainfall intensity. Environmental Monitoring \& Assessment 148, pp. 449-453. doi:10.1007/s10661008-0174-0.

Alexander, K. S., Ryan, A. and Measham, T. G. (2012). Managed retreat of coastal communities: understanding responses to projected sea level rise. Journal of Environmental Planning and Management 55 (4), pp. 409-433.

Allan, R. P., et al. (2010). Current changes in tropical precipitation. Environmental Research Letters 5, pp. 1-7.

Allan, R. P. and Soden, B. J. (2008). Atmospheric warming and the amplification of precipitation extremes. Science 321 (5895), pp. 1481-1484.

Ambrose, B. (1999). Streamflow generation within small rural catchments in a temperate environment: 2 systemic and dynamic modeling. Revue des Sciences de l'Eau 12 (1), pp. 123-153.

Andrishak, R. and Hicks, F. (2008). Simulating the effects of climate change on the ice regime of the Peace River. Canadian Journal of Civil Engineering 35, pp. 461-472.

Ashley, S. T. and Ashley, W. S. (2008). Flood fatalities in the United States. Journal of Applied Meteorology and Climatology 47, pp. 805-818. 
Ashley, W. S., Bentley, M. L. and Stallins, J. A. (2012). Urban-induced thunderstorm modification in the Southeast United States. Climatic Change 113, pp. 481-498.

Ayer, G. R. (2007). Reforestation with conifers - its effect on streamflow in central New York. Journal of the American Water Resources Association 4 (2), pp. 13-24. doi:10.1111/j.1752-1688.1968.tb02932.x.

Barredo, J. I. (2009). Normalized flood losses in Europe: 1970-2006. Natural Hazards and Earth System Science 9, pp. 97-104.

Bastola, S., Murphy, C. and Sweeney, J. (2011). The sensitivity of fluvial risk in Irish catchments to the range of IPCC AR4 climate change scenarios. Science of the Total Environment 409, pp. 5403-5415.

Bavay, M., Lehning, M., Jonas, T. and Lowe, H. (2009). Simulations of future snow cover and discharge in Alpine headwater catchments. Hydrological Processes 23, pp. 95-108. doi:10.1002/hyp.7195.

Beltaos, S. (2007). River ice breakup processes: recent advances and future directions. Canadian Journal of Civil Engineering 34, pp. 703-716.

Bender, F., Ramanathan, V. and Tselioudis, G. (2012). Changes in extratropical storm track cloudiness 1983-2008: observational support for a poleward shift. Climate Dynamics 38, pp. 2037-2053. doi:10.1007/s00382-0111065-6.

Bender, M. A., et al. (2010a). Modeled impact of anthropogenic warning on the frequency of intense Atlantic hurricanes. Science 327 , pp. 454-458.

Benn, D. I., et al. (2012). Response of debris-covered glaciers in the Mount Everest region to recent warming, and implications for outburst flood hazards. Earth-Science Reviews 114(12), pp. 156-174. doi:10.1016/j.earscirev. 2012.03.008.

Bhaduri, B., Minner, M., Tatalovich, S. and Harbor, J. (2001). Long-term hydrologic impact of urbanization: a tale of two models. Journal of Water Resources Planning and Management 127, pp. 13-19.

Bhattacharya, T. and Guleria, S. (2012). Coastal flood management in rural planning unit through land-use planning: Kaikhali, West Bengal, India. Journal of Coastal Conservation 16 (1), pp. 77-87.

Bouwer, L. M. (2011). Have disaster losses increased due to anthropogenic climate change? Bulletin of the American Meteorological Society 92, pp. 39-46. doi:http://dx.doi.org/10.1175/2010BAMS3092.1.

Bradshaw, C. J. A., Sodhi, N. S., Peh, K. S.-H. and Brook, B. W. (2007). Global evidence that deforestation amplifies flood risk and severity in the developing world. Global Change Biology 13, pp. 2379-2395. doi:10.1111/ j.1365-2486.2007.01446.x.

Brissette, F. P., Leconte, R., Marche, C. and Rousselle, J. (2003). Historical evolution of the flooding risk in a USA Quebec river basin. Journal of the American Water Resources Association 39, pp. 1385-1396.

Brommer, D. M., Cerveny, R. S. and Balling, R. C. Jr (2007). Characteristics of long-duration precipitation events across the United States. Geophysical Research Letters 34, pp. L22712.

Bubeck, P., de Moel, H., Bouwer, L. M. and Aerts, J. C. J. H. (2011). How reliable are projections of future flood damage? Natural Hazards and Earth System Science 11, pp. 3293-3306.

Carnell, R. E. and Senior, C. A. (2002). An investigation into the mechanisms of changes in mid-latitude mean sea level pressure as greenhouse gases are increased. Climate Dynamics 18, pp. 533-543.

Catane, S. G., et al. (2012). Landslide-amplified flash floods - the June 2008 Panay Island flooding, Phillipines. Geomorphology, 169-170, pp. 55-63. doi:10.1016/j.geomorph.2012.04.008.

Chang, H. and Franczyk, J. (2008). Climate-change, land-use change, and floods: towards an integrated assessment. Geography Compass 2, pp. 1549-1579. doi:10.1111/j.1749-8198.2008.00136.x.

Charron, D. F., et al. (2004). Vulnerability of waterborne diseases to climate change in Canada: a review. Journal of Toxicology and Environmental Health Part A 67, pp. 1667-1677.

Chen, H., Xu, C.-Y. and Guo, S. (2012). Comparison and evaluation of multiple GCMs, statistical downscaling and hydrological models in the study of climate change impacts on runoff. Journal of Hydrology, 434-435, pp. 36-45.

Chen, Y., et al. (2010). Response of glacial-lake outburst floods to climate change in the Yarkant River basin on northern slope of Karakoram Mountains, China. Quaternary International 226, pp. 75-81.

Chiang, S.-H. and Chang, K.-T. (2011). The potential impact of climate change on typhoon-triggered landslides in Taiwan, 2010-2099. Geomorphology 133 (3-4), pp. 143-151. doi:10.1016/j.geomorph.2010.12.028.

Chung, C.-J. (2006). Using likelihood ratio functions for modeling the conditional probability of occurrence of future landslides for risk assessment. Computers \& Geosciences 32 (8), pp. 1052-1068, doi:10.1016/j.cageo.2006.02.003.

Cohen, B. (2006). Urbanization in developing countries: current trends, future projections, and key challenges for sustainability. Technology in Society 28, pp. 63-80.

Condon, A. J. and Sheng, Y. P. (2012). Evaluation of coastal inundation hazard for present and future climates. Natural Hazards 62, pp. 345-373. doi:10.1007/s11069-011-9996-0.

Cook, K. H., Vizy, E., Launer, Z. and Patricola, C. (2008). Springtime intensification of the Great Plains low-level jet and midwest precipitation in GCM simulations of the twenty-first century. Journal of Climate 21, pp. 63216340 .

Coon, W. F. and Reddy, J. E. (2008). Hydrologic and water-quality characterization and modeling of the Onondaga Lake Basin. Onondaga County, New York: U.S. Geological Survey Scientific Investigations Report 
2008-5013. 85 pp. [Online]. Retrieved on 30 March 2012 from: http://pubs.usgs.gov/sir/2008/5013/SIR 2008-5013.pdf.

Danso-Amoako, E., et al. (2012). Predicting dam failure risk for sustainable flood retention basins: a generic case study for the wider Greater Manchester area. Computers, Environment and Urban Systems 36 (5), pp. $423-433$.

Das, T., Dettinger, M. D., Cayan, D. R. and Hidalgo, H. G. (2011). Potential increase in floods in California's Sierra Nevada under future climate projections. Climatic Change 109, pp. 71-94. doi:10.1007/s10584-011-0298-z.

Dirmeyer, P. A. (2011). Floods and droughts in a changing climate - now and the future. Earthzine. [Online]. Retrieved on 12 July 2012 from: http://www.earthzine.org/2011/04/29/floods-and-droughts-in-a-changingclimate---now-and-the-future/.

Dirmeyer, P. A., et al. (2012). Evidence for enhanced land-atmosphere feedback in a warming climate. Journal of Hydrometeorology 13, pp. 981-995.

Divoky, D., Eberbach, D. and Crowell, M. (2012). The impact of climate change on the National Flood Insurance Program. In: Ayyub, B. and Kearney, M. S. (eds) Sea level rise and coastal infrastructure: prediction, risks and solutions. Reston: American Society of Civil Engineers (ASCE): CAB International, pp. 59-77.

Dixon, T. H., et al. (2006). Subsidence and flooding in New Orleans. Nature 441, pp. 587-588.

D'Orgeville, M. and Peltier, W. R. (2009). Implications of both statistical equilibrium and global warming simulations with CCSM3. Part I: on the decadal variability in the North Pacific basin. Journal of Climate 22, pp. 52775297. doi:10.1175/2009JCLI2428.1.

Dorigo, W. A., et al. (2011). The international soil moisture network: a data hosting facility for global in-situ soil moisture measurements. Hydrology and Earth System Sciences 15, pp. 1675-1698. doi:10.5194/hess-15-1675-2011.

Dwamena, E., Banaynal, R. and Kemausuor, F. (2011). Participatory three dimensional model mapping (P3DM): expanding rural horizons and decision making for food security planning, climate change adaptation and flood risk reduction in Ghana. Research Journal of Agricultural Science 43 (4), pp. 186-195.

Eakin, H. and Appendini, K. (2008). Livelihood change, farming, and managing flood risk in the lerma valley, Mexico. Agriculture and Human Values 25, pp. 555-566. doi:10.1007/s10460-008-9140-2.

Emanuel, K., Sundararajan, R. and Williams, J. (2008). Hurricanes and global warming. Bulletin of the American Meteorological Society 89, pp. 347-367. doi:10.1175/BAMS-89-3-347.

Endreny, T. A. and Imbeah, N. (2009). Generating robust rainfall intensity-duration-frequency estimates with short-record satellite data. Journal of Hydrology 371 (1-4), pp. 182-191.

England, J. F., Jr (2011). Flood frequency and design flood estimation procedures in the United States: progress and challenges. Australian Journal of Water Resources 15, pp. 33-46.

Entekhabi, D., et al. (2010). The soil moisture active passive (SMAP) mission. Proceedings of the IEEE 98 (5), pp. 704-716.

Faroda, A. S. and Poonia, S. (2012). Climate change and Indian agriculture: impacts, adaptation and mitigation strategies. Biological Forum 4, 1-12.

Feyen, L., et al. (2012). Fluvial flood risk in Europe in present and future climates. Climatic Change 112, pp. 47-62.

Frey, H., et al. (2010). A multi-level strategy for anticipating future glacier lake formation and associated hazard potentials. Natural Hazards and Earth System Sciences 10, pp. 339-352.

Furtado, J. C., Di Lorenzo, E., Schneider, N. and Bond, N. A. (2011). North Pacific decadal variability and climate change in the IPCC AR4 models. Journal of Climate 24, pp. 3049-3067. doi:10.1175/2010JCLI3584.1.

Germer, S., Neill, C., Krusche, A. V. and Elsenbeer, H. (2010). Influence of land-use change on near-surface hydrological processes: undisturbed forest to pasture. Journal of Hydrology 380 (3-4), pp. 473-480. doi:10.1016/ j.jhydrol.2009.11.022.

Gersonius, B., Ashley, R., Pathirana, A. and Zevenbergen, C. (2012). Climate change uncertainty: building flexibility into water and flood risk infrastructure. Climatic Change 112, pp. 1-13. doi:10.1007/s10584-012-0494-5.

Ghavasieh, A. R. and Norouzi, A. (2009). Flood-level forecasting using intensity-duration-frequency curves. Australian Journal of Basic and Applied Sciences 3 (4), pp. 4384-4391.

Gillett, N. P. and Stott, P. A. (2009). Attribution of anthropogenic influence on seasonal sea level pressure. Geophysical Research Letters 36, pp. 1-5.

Goodman, S. J., et al. (2012). The GOES-R proving ground: accelerating user readiness for the next-generation geostationary environmental satellite system. Bulletin of the American Meteorological Society 93 (7), pp. 1029-1040. doi:10.1175/BAMS-D-11-00175.1.

Goulding, H. L., Prowse, T. D. and Bonsal, B. (2009). Hydroclimatic controls on the occurrence of break-up and ice-jam flooding in the Mackenzie Delta, NWT, Canada. Journal of Hydrology, 379 (3-4), pp. 251-267.

Griffiths, G. A., Pearson, C. P. and McKerchar, A. I. (2009). Climate variability and the design flood problem. Journal of Hydrology NZ 48, pp. 29-38.

Groisman, P. Y., et al. (2004). Contemporary changes of the hydrological cycle over the contiguous United States: trends derived from in situ observations. Journal of Hydrometeorology 5, pp. 64-85.

Guha-Sapir, D., Vos, F., Below, R. and Ponserre, S. (2012). Annual disaster statistical review 2011: the numbers and trends. Brussels: CRED, pp. 1-52. 
Hegglin, E. and Huggel, C. (2008). An integrated assessment of vulnerability to glacial hazards: a case study in the Cordillera Blanca, Peru. Mountain Research and Development 28 (3/4), pp. 299-309. doi:10.1659/mrd.0976.

Heidari, A. (2009). Structural master plan of flood mitigation measures. Natural Hazards and Earth System Sciences 9 , pp. 61-75.

Hess, J. J., McDowell, J. Z. and Luber, G. (2012). Integrating climate change adaptation into public health practice: using adaptive management to increase adaptive capacity and build resilience. Environmental Health Perspectives 120 (2), pp. 171-179. doi:10.1289/ehp.1103515.

Hill, K. A. and Lackmann, G. M. (2011). The impact of future climate change on TC intensity and structure: a downscaling approach. Journal of Climate 24, pp. 4644-4661. doi:10.1175/2011JCLI3761.1.

Hu, Z.-Z., Latif, M., Roeckner, E. and Bengtsson, L. (2000). Intensified Asian summer monsoon and its variability in a coupled model forced by increasing greenhouse gas concentrations. Geophysical Research Letters 27, pp. 26812684.

Huggel, C., et al. (2002). Remote sensing based assessment of hazards from glacier lake outbursts: a case study of the Swiss Alps. Canadian Geotechnical Journal 39, pp. 316-330. doi:10.1139/T01-099.

Huntington, T. G. (2006). Evidence for intensification of the global water cycle: review and synthesis. Journal of Hydrology 319, pp. 83-95.

Hunukumbura, P. B. and Tachikawa, Y. (2012). River discharge projection under climate change scenario in the Chao Phraya river basin. Journal of the Meteorological Society of Japan 90A, pp. 137-150.

Huong, H. T. L. and Pathirana, A. (2011). Urbanization and climate change impacts on future urban flood risk in Can Tho city, Vietnam. Hydrology and Earth System Sciences Discussions 8, 10781-10824. doi:10.5194/hessd-810781-2011.

Hurrell, J. W. and Deser, C. (2009). North Atlantic climate variability: the role of the North Atlantic Oscillation. Journal of Marine Systems 78 (1), pp. 28-41.

IPCC (2012). Summary for policymakers. In: Field, C. B., Barros, V., Stocker, T. F., Qin, D., Dokken, D. J., Ebi, K. L., Mastrandrea, M. D., Mach, K. J., Plattner, G.-K., Allen, S. K., Tignor, M. and Midgley, P. M. (eds), Managing the risks of extreme events and disasters to advance climate change adaptation [A special report of working groups I and II of the intergovernmental panel on climate change]. Cambridge and New York: Cambridge University Press, pp. 1-19. [Online]. Retrieved on 14 September 2012 from: http://www.ipccwg2.gov/SREX/images/uploads/SREX-SPMbrochure_FINAL.pdf.

Irons, J. R., Dwyer, J. L. and Barsi, J. A. (2012). The next Landsat satellite: the Landsat Data Continuity Mission. Remote Sensing of the Environment 122, pp. 11-21. doi:10.1016/j.rse.2011.08.026.

Jain, S. and Lall, U. (2001). Floods in a changing climate: does the past represent the future? Water Resources Research 37, pp. 3193-3205.

Jakob, M. and Lambert, S. (2009). Climate change effects on landslides along the southwest coast of British Columbia. Geomorphology 107 (3-4), pp. 275-284. doi:10.1016/j.geomorph.2008.12.009.

Jevrejeva, S., Moore, J. C. and Grinsted, A. (2012). Sea level projections to AD2500 with a new generation of climate change scenarios. Global and Planetary Change, 80-81, pp. 14-20.

Jones, C. and Carvalho, L. M. V. (2011). Will global warming modify the activity of the Madden-Julian Oscillation? Quarterly Journal of the Royal Meteorological Society 137 (655), pp. 544-552.

Kay, A., Davies, H., Bell, V. and Jones, R. (2009). Comparison of uncertainty sources for climate change impacts: flood frequency in England. Climatic Change 92, pp. 41-63.

Kim, J.-H., Brown, S. J. and McDonald, R. E. (2011). Future changes in tropical cyclone genesis in fully dynamic ocean- and mixed layer ocean-coupled climate models: a low-resolution model study. Climate Dynamics 37, pp. 737-758.

Kingsford, R. T. (2000). Ecological impacts of dams, water diversions and river management on floodplain wetlands in Australia. Austral Ecology 25 (2), pp. 109-127.

Kirshen, P., et al. (2008). Coastal flooding in the northeastern United States due to climate change. Mitigation $\mathcal{E}$ Adaptation Strategies for Global Change 13 (5/6), pp. 437-451. doi:10.1007/s11027-007-9130-5.

Kleinen, T. and Petschel-Held, G. (2007). Integrated assessment of changes in flooding probabilities due to climate change. Climatic Change 81, pp. 283-312.

Knowles, N. and Cayan, D. R. (2002). Potential effects of global warming on the Sacramento/San Joaquin watershed and the San Francisco estuary. Geophysical Research Letters 29 (18), pp. 1-4. doi:10.1029/ 2001 GL014339.

Krajewski, W. F., et al. (2011). Towards better utilization of NEXRAD data in hydrology: an overview of HydroNEXRAD. Journal of Hydroinformatics 13 (2), pp. 255-266. doi:10.2166/hydro.2010.056.

Kwon, H.-H., Sivakumar, B., Moon, Y.-I. and Kim, B.-S. (2011). Assessment of change in design flood frequency under climate change using a multivariate downscaling model and a precipitation-runoff model. Stochastic Environmental Research and Risk Assessment 25, pp. 567-581.

Larson, K. M., et al. (2008). Use of GPS receivers as a soil moisture network for water cycle studies. Geophysical Research Letters 35, pp. L24405. doi:10.1029/2008GL036013. 
Lee, S.-Y., Hamlet, A., Fitzgerald, C. and Burges, S. (2009). Optimized flood control in the Columbia River Basin for a global warming scenario. Journal of Water Resources Planning and Management 135, pp. 440-450.

Li, J., Wu, Z., Jiang, Z. and He, J. (2010). Can global warming strengthen the East Asian summer monsoon? Journal of Climate 23, pp. 6696-6705.

Li, L., et al. (2008). Impact of future climate change on runoff in the head region of the Yellow River. Journal of Hydrologic Engineering 13 (5), pp. 347-354. doi:10.1061/(ASCE)1084-0699(2008)13:5(347).

te Linde, A. H., et al. (2011). Future flood risk estimates along the river Rhine. Natural Hazards and Earth System Sciences 11, pp. 459-473.

Lopez Saez, J., Corona, C., Stoffel, M. and Berger, F. (2012). High-resolution fingerprints of past landsliding and spatially explicit, probabilistic assessment of future activations: Aiguettes landslide, southeastern French Alps. Tectonophysics pp. 1-15. (in press) doi:10.1016/j.tecto.2012.04.020.

López-Moreno, J. I., et al. (2011). Effects of the North Atlantic Oscillation (NAO) on combined temperature and precipitation winter modes in the Mediterranean mountains: observed relationships and projections for the 21st century. Global and Planetary Change 77 (1-2), pp. 62-76.

Lorenz, D. J. and DeWeaver, E. T. (2007). Tropopause height and zonal wind response to global warming in the IPCC scenario integrations. Journal of Geophysical Research 112, pp. 1-11. doi:10.1029/2006JD008087.

Maaskant, B., Jonkman, S. N. and Bouwer, L. M. (2009). Future risk of flooding: an analysis of changes in potential loss of life in South Holland (The Netherlands). Environmental Science \& Policy 12 (2), pp. $157-169$. doi:10.1016/j.envsci.2008.11.004.

Madsen, H., Arnbjerg-Nielsen, K. and Mikkelsen, P. S. (2009). Update of regional intensity-duration-frequency curves in Denmark: tendency towards increased storm intensities. Atmospheric Research 92 (3), pp. 343-349.

Mcleman, R. and Smit, B. (2006). Vulnerability to climate change hazards and risks: crop and flood insurance. The Canadian Geographer 50 (2), pp. 217-226. doi:10.1111/j.0008-3658.2006.00136.x.

Meehl, G. A., Arblaster, J. M. and Tebaldi, C. (2005). Understanding future patterns of increased precipitation intensity in climate model simulations. Geophysical Research Letters 32, pp. 1-4.

Mills, E. (2005). Insurance in a climate of change. Science 309 (5767), pp. 1040-1044. doi:10.1126/science.1112121.

Milly, P. C. D., Dunne, K. A. and Vecchia, A. V. (2005). Global pattern of trends in streamflow and water availability in a changing climate. Nature 438, pp. 347-350.

Min, S. K., Zhang, X., Zwiers, F. and Hegerl, G. (2011). Human contribution to more intense precipitation extremes. Nature 470, pp. 378-381.

Mirza, M. M. Q. (2002). Global warming and changes in the probability of occurrence of floods in Bangladesh and implications. Global Environmental Change 12 (2), pp. 127-138.

Moore, R. J. (2007). The PDM rainfall-runoff model. Hydrology and Earth System Science 11, pp. $483-499$.

Morita, M. (2011). Quantification of increased flood risk due to global climate change for urban river management planning. Water Science and Technology 63, pp. 2967-2974.

Müller, A. and Reinstorf, F. (2011). Exploration of land-use scenarios for flood hazard modeling - the case of Santiago de Chile. Hydrology \& Earth System Sciences Discussions 8, pp. 3993-4024. doi:10.5194/hessd-8-39932011.

Murikami, H., et al. (2012). Future changes in tropical cyclone activity projected by the new high-resolution MRI-AGCM. Journal of Climate 25, pp. 3237-3260. doi:10.1175/JCLI-D-11-00415.1.

Naidu, C. V., et al. (2012). Changes in the frequencies of northeast monsoon rainy days in the global warming. Global and Planetary Change 92-93, pp. 40-47. doi:10.1016/j.gloplacha.2012.04.009.

National Academy of Sciences. (2012). Urban Meteorology: Forecasting, monitoring, and meeting users' needs. Committee on Urban Meteorology. Washington, DC: National Academies Press, pp. 1-176. [Online]. Retrieved on 15 September 2012 from: http://www.nap.edu/catalog.php?record_id=13328.

Ning, L., et al. (2012). Probabilistic projections of anthropogenic climate change impacts on precipitation for the mid-Atlantic region of the United States. Journal of Climate 25, pp. 5273-5291. doi:10.1175/JCLI-D-11-00565.1.

Nowak, D. and Walton, J. (2005). Projected urban growth (2000-2050) and its estimated impact on the US forest resource. Journal of Forestry 103, pp. 383-389.

Nugent, K. A. and Matthews, H. D. (2012). Drivers of future northern latitude runoff change. Atmosphere-Ocean 50 (2), pp. 197-206. doi:10.1080/07055900.2012.658505.

Ouellet, C., Saint-Laurent, D. and Normand, F. (2012). Flood events and flood risk assessment in relation to climate and land-use changes: Saint-François River, southern Québec, Canada. Hydrological Sciences Journal 57, pp. 313-325.

Pall, P., Allen, M. R. and Stone, D. A. (2007). Testing the Clausius-Clapeyron constraint on changes in extreme precipitation under $\mathrm{CO}_{2}$ warming. Climate Dynamics 28, pp. 351-363.

Pall, P., et al. (2011). Anthropogenic greenhouse gas contribution to flood risk in England and Whales in autumn 2000. Nature 470, pp. 382-386. doi:10.1038/nature09762.

Panahi, A., Alijani, B. and Mohammadi, H. (2010). The effect of land use/cover changes on the floods of the Madarsu Basin of northeastern Iran. Journal of Water Resource and Protection 2, pp. 373-379. doi:10.4236/ jwarp.2010.24043. 
Pegg, M. A., Pierce, C. L. and Roy, A. (2003). Hydrological alteration along the Missouri River Basin: a time series approach. Aquatic Sciences 65, pp. 63-72.

Petrakov, D., et al. (2012). Monitoring of Bashkara glacier lakes (Central Caucasus, Russia) and modeling their potential outburst. Natural Hazards 61 (3), pp. 1293-1316. doi:10.1007/s11069-011-9983-5.

Pitlick, J. (1997). A regional perspective of the hydrology of the 1993 Mississippi River basin floods. Annals of the Association of American Geographers 87 (1), pp. 135-151.

Poelmans, L., Rompaey, A. and Batelaan, B. (2010). Coupling urban expansion models and hydrological models: how important are spatial patterns? Land Use Policy 27, pp. 965-975. doi:10.1016/j.landusepol.2009.12.010.

Qiu, Y., et al. (2010). Valuation of flood reductions in the Yellow River basin under land use change. Journal of Water Resources Planning \& Management 136 (1), pp. 106-115. doi:10.1061/(ASCE)0733-9496(2010)136:1(106).

Rebora, N., Ferraris, L., von Hardenberg, J. and Provenzale, A. (2006). Rainfall downscaling and flood forecasting: a case study in the Mediterranean area. Natural Hazards and Earth System Sciences 6, pp. 611-619.

Refsgaard, J. C. (1997). Parameterisation, calibration and validation of distributed hydrological models. Journal of Hydrology 198 (1-4), pp. 69-97.

Reges, H. W., et al. (2010). CoCoRaHS (the Community Collaborative Rain, Hail and Snow network); on-line citizen science engaging the public in precipitation monitoring. In: Abstracts with Programs - Geological Society of America, Denver, 2010. Boulder: GSA, pp. 407.

Reynard, N., Crooks, S., Wilby, R. and Kay, A. (2004). Climate change and flood frequency in the UK. In: 39th Defra Flood and Coastal Flood Management Conference, York, 2004. London: Flood Management Division.

Reynolds, S., Burian, S., Shepherd, J. M. and Manyin, M. (2008). Chapter 7: urban induced rainfall modifications on urban hydrologic response. In: James, W., Irvine, K. N., McBean, E. A., Pitt, R. E. and Wright, S. J. (eds) Reliable modeling of urban water systems. Guelph, Ontario: Computational Hydraulics International, pp. 92-122.

Rivière, G. (2011). A dynamical interpretation of the poleward shift of the jet streams in global warming scenarios. Journal of the Atmospheric Sciences 68, pp. 1253-1272.

Ryzhkov, A. V., et al. (2005). The joint polarization experiment: polarimetric rainfall measurements and hydrometeor classification. Bulletin of the American Meteorological Society 86 (6), pp. 809-824.

Sabade, S. S., Kulkarni, A. and Kripalani, R. H. (2011). Projected changes in South Asian summer monsoon by multi-model global warming experiments. Theoretical \& Applied Climatology 103, pp. 543-565. doi:10.1007/ s00704-010-0296-5.

Sarthi, P., Dash, S. K. and Mamgain, A. (2012). Possible changes in the characteristics of Indian Summer Monsoon under warmer climate. Global and Planetary Change 92-93, pp. 17-29.

Schiermeier, Q. (2011). Increased flood risk linked to global warming. Nature 470, pp. 316.

Schijven, J. F. and Husman, A. M. de. R. (2005). Effect of climate changes on waterborne disease in The Netherlands. Water Science \& Technology 51 (5), pp. 79-87.

Shem, W. and Shepherd, M. (2009). On the impact of urbanization on summertime thunderstorms in Atlanta: two numerical model case studies. Atmospheric Research 92 (2), pp. 172-189.

Shepherd, J. M. (2005). Making rain: do cities impact precipitation? Weatherwise Sept/Oct, pp. $28-31$.

Shepherd, J. M. and Knutson, T. (2007). The current debate on the linkage between global warming and hurricanes. Geography Compass, 1 pp. 1-24. doi:10.1111/j.1749-8198.2006.00002.x.

Shepherd, M., et al. (2011). An overview of synoptic and mesoscale factors contributing to the disastrous Atlanta flood of 2009. Bulletin of the American Meteorological Society 92, pp. 861-870. doi:10.1175/2010BAMS3003.1.

Shiho, T. and Osafumi, S. (2008). Global warming thaws Himalayan glaciers at frightening speed. Asian-Pacific Journal: Japan Focus 3, pp. 1.

Shrestha, A. B. and Aryal, R. (2011). Climate change in Nepal and its impact on Himalayan glaciers. Regional Environmental Change 11, pp. 65-77. doi:10.1007/s10113-010-0174-9.

Soares, W. R. and Marengo, J. A. (2009). Assessments of moisture fluxes east of the Andes in South America in a global warming scenario. International Journal of Climatology 29, pp. 1395-1414.

Stoffel, M. and Huggel, C. (2012). Effects of climate change on mass movements in mountain environments. Progress in Physical Geography 36 (3), pp. 421-439. doi:10.1177/0309133312441010.

Tao, F., Yokozawa, M., Hayashi, Y. and Lin, E. (2003). Terrestrial water cycle and the impact of climate change. Ambio 32, 295-301.

Tapiador, F. J., et al. (2012). Global precipitation measurement: methods, datasets and applications. Atmospheric Research 104-105, pp. 70-97. doi:10.1016/j.atmosres.2011.10.021.

Tol, R. S. J., van der Grijp, N., Olsthoorn, A. A., and van der Werff, P. E. (2003). Adapting to climate: a case study on riverine flood risks in the Netherlands. Risk Analysis 23, pp. 575-583.

Tramblay, Y., Qin, D., Manning, M., Marquis, M., Averyt, K., Tignor, M. M. B, Miller, H. L., Jr., and Zhenlin, C. (2012). Climate change impacts on extreme precipitation in Morocco. Global and Planetary Change 82-83, pp. $104-114$

Trenberth, K. E. (2011). Changes in precipitation with climate change. Climate Research 47, pp. 123-138. 
Trenberth, K. E., et al. (2007). Observations: surface and atmospheric climate change. In: Solomon, S., et al. (eds) Climate change: the physical science basis. Contribution of Working Group I to the Fourth Assessment Report of the Intergovernmental Panel on Climate Change. Cambridge, UK: Cambridge University Press, pp. 235-336.

Ueda, H., Iwai, A., Kuwake, K. and Hori, M. (2006). Impact of anthropogenic forcing on the Asian summer monsoon as simulated by eight GCMs. Geophysical Research Letters 33, pp. 2533-2536.

Usmani, J. and Vachani, S. (2011). Climate change and coastal protection. The Journal for Decision Makers 36, pp. 104-106.

Van Den Eeckhaut, M., et al. (2009). Evidence for repeated re-activation of old landslides under forest. Earth Surface Processes and Landforms 34, pp. 352-365. doi:10.1002/esp.1727.

Van Oldenborgh, G. J., van Urk, A. and Allen, M. (2012). The absence of a role of climate change in the 2011 Thailand floods. Bulletin of the American Meteorological Society 93, pp. 1047-1049.

Villarini, G., et al. (2010a. Radar analyses of extreme rainfall and flooding in urban drainage basins. Journal of Hydrology 381 (3-4), pp. 266-286. doi:10.1016/j.jhydrol.2009.11.048.

Villarini, G., et al. (2010b). Towards probabilistic forecasting of flash floods: the combined effects of uncertainty in radar-rainfall and flash flood guidance. Journal of Hydrology 394 (1-2), pp. 275-284.

Wasowski, J., Keefer, D. K. and Lee, C.-T. (2011). Toward the next generation of research on earthquake-induced landslides: current issues and future challenges. Engineering Geology 122 (1-2), pp. 1-8. doi:10.1016/j.enggeo.2011.06.001.

Westcott, N. E., Knapp, H. V. and Hilberg, S. D. (2008). Comparison of gage and multi-sensor precipitation estimates over a range of spatial and temporal scales in the Midwestern United States. Journal of Hydrology 351 (1-2), pp. 1-12. doi:10.1016/j.jhydrol.2007.10.057.

Wetherald, R. T. and Manabe, S. (2002). Simulation of hydrologic changes associated with global Warming. Journal of Geophysical Research 107, pp. 1-15.

Wijesekara, G. N., et al. (2012). Assessing the impact of future land-use changes on hydrological processes in the Elbow River watershed in Southern Alberta, Canada. Journal of Hydrology 412-413, pp. 220-232. doi:10.1016/ j.jhydrol.2011.04.018.

Wilby, R. L. and Keenan, R. (2012). Adapting to flood risk under climate change. Progress in Physical Geography 36 (3), pp. 348-378. doi:10.1177/0309133312438908.

Wissmar, R. C., Timm, R. K., and Logsdon, M. G. (2004). Effects of changing forest and impervious land covers on discharge characteristics of watersheds. Environmental Management 34, pp. 91-98. doi:10.1007/s00267-0040224-5.

Wood, M., et al. (2012). Flood risk management: US Army Corps of Engineers and Layperson Perceptions. Risk Analysis 32 (8), pp. 1349-1368. doi:10.1111/j.1539-6924.2012.01832.x.

Wu, Y., et al. (2011). Changes in storm tracks and energy transports in a warmer climate simulated by the GFDL CM2.1 model. Climate Dynamics 37, pp. 53-72.

Xia, J., Chen, S. and Wan, S. (2010). Impacts of day versus night warming on soil microclimate: results from a semiarid temperate steppe. Science of the Total Environment 408, pp. 2807-2816.

Yin, J. H. (2005). A consistent poleward shift of the storm tracks in simulations of 21st century climate. Geophysical Research Letters 32, L18701. doi:10.1029/2005GL023684.

Zhang, Y., et al. (2012). ENSO anomalies over the Western United States: present and future patterns in regional climate simulations. Climatic Change 110, pp. 315-346. doi:10.1007/s10584-011-0088-7.

Zheng, J., Liu, Q. and Huang, F. (2011). Response of Asian summer monsoon to $\mathrm{CO}_{2}$ doubling. Journal of Oceanography 10, pp. 210-218.

Zuo, Z., et al. (2012). Role of thermal condition over Asia in the weakening Asian summer monsoon under global warming background. Journal of Climate 25, pp. 3431-3436. 